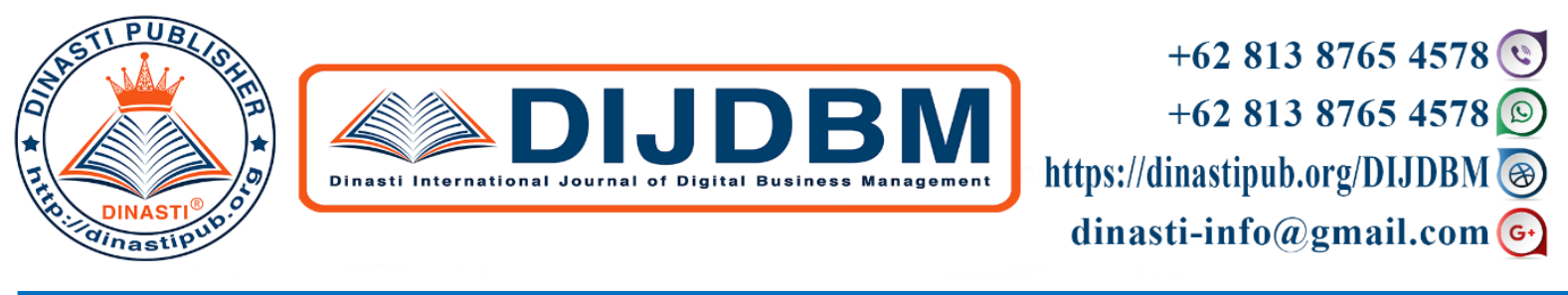

\title{
INCREASED PRODUCTIVITY OF HUMAN RESOURCES BASED ON KEY PERFORMANCE INDICATOR AND TRAINING
}

\author{
Kusnadi $^{1}$ \\ ${ }^{1)}$ Sekolah Tinggi Manajemen IMMI, Jakarta, Indonesia
}

ARTICLE INFORMATION

Received: 24 August 2020

Revised: 25 September 2020

Issued: 31 October 2020

Corresponding author: Kusnadi

\section{E-mail: \\ hamaskus@yahoo.com}

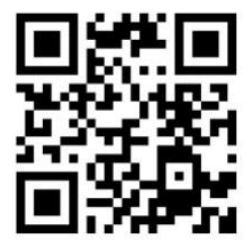

DOI:10.31933/DIJDBM
Abstract: This study aims to discuss methods in an effort to increase human resource productivity in a company based on Key Performance Indicators (KPI) and providing training. The concept of human resource development is a way that is carried out with the intention of making human resources a source of competitive advantage, based on practical experience that effective human resource development can increase work productivity, morale, and the potential in institutions, development programs. The assumption of work productivity can be seen as a mental attitude that always has the view that today's life must be better than yesterday and tomorrow must be better than today. Employees who have this attitude will be encouraged to be dynamic, creative, and open while remaining critical and responsive to new ideas and changes. This requires an appropriate human resource development strategy. Work productivity is the result of the interaction between work ability (ability) and motivation (motivation). Work motivation can be influenced by the physical condition, social conditions of the work environment, as well as the basic needs of employees. Productivity can be interpreted, among other things, from the aspect of individual appearance. Thus, employees who have the ability and high motivation in carrying out their duties will be able to support the organization by becoming a productive employee characterized by fulfilling job qualifications, positive job orientation, maturity, highly motivated, and able to get along effectively.

Keywords: Increased Productivity, Human Resources, Key Performance Indicator; Training.

\section{INTRODUCTION}

Companies are expected to continue to make changes and keep abreast of existing developments. To carry out company activities, production factors and Human Resources (HR) are needed. The HR factor is not only a tool, but plays an important role in increasing the effectiveness and determining the success of a company to achieve its goals. Human resources are not only part of the production process, but as social beings with unique 
characteristics and different needs. However, the human resource factor with good and high abilities does not guarantee the company to increase its productivity, but is influenced by external factors such as leadership and compensation. This is a problem that can be evaluated because the company's productivity has not been maximally achieved. So it is necessary to find solutions to existing problems along with factors that greatly influence productivity improvement such as implementing Key Performance Indicators and providing training, thus the solution to the existing problems lies in how the company makes efforts to manage HR so that they want to provide capabilities. the best for the company.

Human resource development is intended to increase the work productivity of individuals, groups and the entire organization. This is very important because people, technology, jobs, and organizations are always changing so that employees need to receive training and continue to be developed. This step was taken to make them as personnel who mastered technology in order to achieve the stated goals. This training and development must be carried out since employees enter a job and continue as career development.

A person's ability to work starts from the education and training that is followed. Education and training are basically a means for increasing human knowledge and skills as well as providing changes in attitudes and encouragement for achievement. Intensive education and training will increase one's skills so that the resulting workers will be of higher quality and quickly completed. In other words, education and training are open opportunities for someone to do better. Opportunities in this case at the same time include: 1) Opportunities to work 2) Jobs in accordance with education, skills and interests 3) Opportunities for achievement and self-development. Work productivity is the result of the interaction between work ability (ability) and motivation (motivation). The ability is shaped and influenced by knowledge and skills. The factors that determine knowledge include education, experience, training and desire. The skills are influenced by talent, intelligence, and personality. Work motivation can be influenced by the physical condition, social conditions of the work environment, as well as the basic needs of employees. Productivity can be interpreted, among other things, from the aspect of individual appearance. Thus, employees who have the ability and high motivation in carrying out their duties will be able to support the organization by becoming a productive employee characterized by fulfilling job qualifications, positive job orientation, maturity, highly motivated, and able to get along effectively.

According to Sedarmayanti (2004), productivity is how to produce or increase the highest possible output of goods and services by utilizing human resources efficiently. Productivity is an achievement of the work of employees in an effort to achieve established organizational goals. For this reason, there are two important aspects of work productivity, namely: 1) Efficiency, which is a measure in comparing the use of planned inputs with the inputs that are actually implemented. If the actual input is used for greater savings, the level of efficiency will be higher. In this case what is meant is as follows: (a) Timeless, is the degree to which an activity is completed at the desired time by taking into account the coordination of other outputs and the time available for other activities, (b) Costeffectiveness, is the level to which the use of organizational power (human, financial, technology, and material) is maximized to achieve results, (c) Need for supervision, is the degree to which a worker can carry out a job function without requiring supervision of a supervisor to prevent unwanted actions, and (d) Interpersonal impact, is the extent to which workers maintain themselves, good name and cooperation among colleagues and subordinates. 2) Effectiveness, is a measure that gives an idea of how far the target can be achieved both in quality and time. If the percentage of the target that can be achieved is greater, the higher the level of effectiveness or the smaller the percentage of the target that 
can be achieved, the lower the level of effectiveness. In this case, what is included in the effectiveness is as follows: (a) Quality, is the level to which the process or the results of the implementation of activities close to perfection or close to the expected goals, and (b) Quantity, is the level to which the amount produced. In the description of the aspects of work productivity above, it can be concluded that work productivity can produce good performance from employees effectively and efficiently, to achieve the goals of an organization.

Work productivity. According to Yuniarsih and Suwanto (2009), work productivity can be interpreted as a concrete result (product) produced by individuals or groups during a certain time unit in a work process. In this case, the higher the product produced in a shorter time, it can be said that the level of productivity has a high value. Productivity can be interpreted as the ratio between real work (output) in the form of goods and services and the actual input (input).

According to Susilowati (2016), work productivity, which is employee performance as a manifestation, is a performance appraisal or job assessment, often having problems. This obstacle is in the form of work assessments that are not in accordance with employee performance. Bosses sometimes provide job appraisals that often follow an element of subjectivity. So that the job appraisal is high, but the performance in their daily work tends to be low. This will later have an impact on the management of human resources, namely employees in the company. Companies will experience difficulties in improving employee performance which will have an impact on work productivity.

According to J. Ravianto (1989), productivity is a mental attitude that glorifies work and is based on strong motivation to continually strive to achieve a better quality of life. Increased productivity will have an impact on improving the quality of life for the better. Basically, every company wants high productivity from its employees, because with high employee productivity, the company has high expectations of profit as well.

According to Rivai (2005), Key Performance Indicator (KPI) is a quantitative and gradual measure for companies that has various perspectives and is based on concrete data, and is a starting point for setting goals and formulating organizational strategies. According to Warren (2011), Key Performance Indicator (KPI) is a measurement that assesses how an organization executes its strategic vision. The strategic vision in question refers to how the organizational strategy is interactively integrated into the overall organizational strategy. According to Simamora (2005), defines Key Performance Indicator (KPI) as the most critical for organizational success in present and future conditions. According to Banerjee and Buoti (2012), Key Performance Indicator (KPI) is a scale and quantitative measure used to evaluate organizational performance in achieving organizational targets. KPIs are also used to define measurable objectives, see trends, and support decision making.

According to Bernardin and Russell, Training is defined as any attempt to improve employed performance on a currently held job or one related to it. This usually means changes in specific knowledges, skills, attitudes, or behaviors. To be effective, training should involve a learning experience, be a planned organizational activity, and be designed in response to identified needs. This means that training is defined as various introductory efforts to develop workforce performance in the work carried out or also something related to their work. This usually means making specific or specific changes in behavior, attitudes, skills, and knowledge. The way that training is effective, in training must include a learning of experiences, training must be an organizational activity that is planned and designed in response to identified needs. According to Noe, Hollenbeck, Gerhart and Wright, training is a planned effort to facilitate the learning of job-related knowledge, skills, and behavior by 
employee. This means that training is a planned effort to facilitate learning about work related to knowledge, skills and behavior by employees. Meanwhile, according to Dessler, the definition of training is to give new or old employees the skills they need to carry out their jobs. Thus training means showing a machinist how to operate his new machine, for a new salesperson, how to sell his company's products, or for a new supervisor how to interview and assess employees.

\section{RESEARCH METHODS}

The research method used is a qualitative research method through literature studies, literature review from the point of view of human resource management, and analyzing the results of employee performance in a company organization, in this study will describe the level of explanation of Key Performance Indicator based Human Resource Productivity Increase Training. The data analysis used in this research is descriptive analysis. Descriptive research aims to provide a description in the form of descriptions in the form of words about the research subject from observations of a problem. The results of the research are then analyzed to find identification of ways to increase the productivity of human resources using the Key Performance Indicator (KPI) method and providing training to employees.

\section{FINDINGS AND DISCUSSION}

Competition in the business world is currently increasing so that everyone is required to be able to face all kinds of challenges that exist. Various kinds of challenges faced by every organization arise from various sources, both from within and from outside the organization. Challenges that come from outside include technological advances, crisis situations that cause the economy to slow down, laws and regulations issued by the government and so on. Besides challenges from outside, barriers that come from within the organization itself pose a problem in itself, for example how an organization can meet the needs of its members and how to maintain relationships between members of the organization in order to reduce conflicts that can hinder the achievement of organizational goals. All these challenges must be faced seriously, so that the organization is able to face the main challenge, namely how the organization can develop sustainably, so that the organization does not only develop for a moment, then decline and eventually die. This can be achieved if the organization can utilize all the resources that are owned and are scarce efficiently and effectively.

In an organization, the problem often faced by a leader is how to do it to increase work productivity. This is related to efforts to motivate employees to supervise and create an effective work culture and create a comfortable and consusive work environment. This aims to be able to encourage employees to work optimally so that they can produce maximum work productivity and can support the achievement of goals within the organization, the work productivity of an employee in a company is influenced by high motivation and on target in very conditions determine for the company. Productivity and success are important things for leaders in increasing company profits. thus motivation and productivity have influence and a very close and interrelated relationship and it is important for the company to be carried out in a sustainable manner. Thus the purpose of this study was to determine the effect of Key Performance Indicators and Training on increasing the productivity of human resources.

It is necessary to note that the productivity of a company will be inactive or constant and as long as the company still has activities, the increase will vary according to the activities carried out in the company concerned. A company will have a productivity level that varies from year to year, or from one month to another. Within the company, this productivity can be used as a measuring tool for the use of or production equipment (facilities 
/ facilities) in the company concerned. To increase work productivity requires entrepreneurial organizational planning to enter the business world. Planning has a meaning, namely as a process of determining how people can achieve their goals, in line with that planning is a process to determine organizational goals as well as the goals of the life of the people of the nation and state.

Challenges in the era of globalization and a competitive market demand the resilience and competitiveness of a group, community, organization and country in the form of developing human resources as intellectual assets to be an important factor in supporting the productivity and competitive advantage of a company. Strategic HR development is a requirement for every organization to align training programs with organizational strategy. In addition, HR development requires a synergy between aspects of learning (learning) and aspects of performance (performance). For this reason, human resource development through training programs in the workplace requires a means and facilities, namely the Training center. To realize the efforts to improve learning and performance, a professional competency standard is needed, especially for training managers to manage a training center in an organization. The issue of certification is very hotly discussed by various groups, especially those involved in the process of professional development, be it education, health, finance, government and society. The issue of certification is one of the methods used in building a professional career structure and developing quality or quality.

\section{CONCLUSION AND SUGGESTION}

The conclusion must be related to the title and purpose of the study. Don't make statements that are not adequately supported by your findings. Write down the improvements made in the field of industrial engineering or science in general. Don't make further discussions, repeat abstracts, or just list the results of the study. Don't use bullet points, use paragraph sentences instead.

\section{Conclusion}

Control and evaluation are important functions in management to ensure the organization's work plan can run well so that the final goals of the organization can be achieved. To be able to perform control and evaluation functions properly, a good performance management system is needed. A good performance management system must be able to describe the business processes that occur in the organization as a whole. The performance management system can be measured using KPI (Key Performance Indicator)

Key Performance Indicators must be chosen carefully to reflect important performance indicators for the organization according to the company strategy and key factors for organizational success. The determination of Key Performance Indicators and targets to be achieved cannot be done carelessly, but must be selected and determined using an appropriate and systematic method. Selecting Key Performance Indicators and setting Key Performance Indicator targets appropriately will lead organizations to identify potential improvements or performance improvements so that Key Performance Indicators are often associated with initiatives related to performance improvement As one of the main tools of organizational management, the main objective of establishing Key Performance These indicators are: 1. To link the vision-mission-values, organizational strategy, and organizational performance goals with organizational activities to achieve the desired performance goals. 2. To measure the trend of organizational and / or divisional performance whether there is a significant increase or decrease. 3. To compare the current performance of the organization with the historical 
performance of the organization, or to compare it with the performance of other organizations so that the organization gets a picture of the advantages or disadvantages of the organization compared to competitors, and knows opportunities to create added value. 4. The organization's Key Performance Indicator is used as the basis for determining the Key Performance Indicator or work targets for divisions and individuals. 5. The results of the Key Performance Indicator achievement become the basis for providing rewards and consequences so that the Key Performance Indicator is also useful for encouraging work motivation and good behavior from employees.

In a company, if an employee is assigned to a certain position or if an old employee is placed in a new position, so that the employee can complete his duties, it is necessary to first be given additional training or education. Training is carried out to help employees gain effectiveness in work for the short-term educational process utilizing systematic and organized procedures, where non-managerial personnel learn technical skills and knowledge for specific purposes, general purpose training and development programs must be directed to increase organizational productivity.

The training method must be based on the needs of the job depending on various factors, namely time, cost, number of participants, participants 'basic education level, participants' backgrounds, and others. The following are training methods such as: 1 . On the job Direct training places work in place to learn and imitate a job under the guidance of a supervisor. This training method is divided into 2 ways, namely formally and informally. 2 . Vestibule The method of training carried out in a class held in an industrial company to introduce work to new employees and train them to do the job. 3. Demonstration and Example. The training method is carried out by demonstrating and explaining how to do a job through demonstrated examples or experiments. 4. Simulation is a situation or event that is displayed as closely as possible to the actual situation but is only an imitation. Simulation is a technique for imitating as closely as possible the actual concept of the work that will be encountered. 5. Apprenticeship A way to develop carpentry skills so that employees can learn all aspects of their job, a way to develop skills so that employees can learn all aspects of their job. 6. Classroom Methods Classroom meeting methods include lectures, conferences, programmed instruction, case study methods, role playing, discussion methods and seminar methods.

\section{REFERENCE}

Bernardin And Russell, (1998), Human Resource Management, Second Edition, (Singapore: McGraw-Hill Book Co.

Gary Dessler, (1997), Human Resource Management, ed. Ke 7, terj. Benyamin, Prentice Hall, Inc.,New Jersey

J. Ravianto, (1990). Manajemen Personalia. Jakarta : Ghalia Indonesia

Raymond Noe, John Hollenbeck, Barry Gerhart, Patrick Wright, (2003) Human Resource Management, International Edition, (The McGraw-hill Companies : Inc. New York.

Rivai, V dan Basri, M. F. A. (2005). Performance Appraisal. Jakarta: PT. Raja Grafindo Persada

Sedarmayanti, (2004). Manajemen Sumber Daya Manusia. Bumi Aksara. Jakarta

Simamora, (2009). Manajemen Sumber Daya Manusia, Gramedia, Jakarta

Susilowati. (2016). Sumber Daya Manusia Dan Produktivitas Kerja. Bandung : Mandar Maju Yuniarsih Tjutju, dan Suwanto, (2009). Manajemen Sumber Daya Manusia. Bandung: Alpabeta. 
Warren, (2011). Key performance indicators (KPI) - definition and action: Integrating KPIs into your company's strategy. London: ATI. 